The Journal of Animal \& Plant Sciences, 30(5): 2020, Page: 1163-1171

ISSN (print): 1018-7081; ISSN (online): 2309-8694

\title{
CHEMICAL COMPOSITION AND ACARICIDAL ACTIVITIES OF JATROPHA CURCAS L. EXTRACT AGAINST ORIENTAL RED MITE, EUTETRANYCHUS ORIENTALIS (KLEIN) (ACARI: TETRANYCHIDAE)
}

\author{
H. Alahyane ${ }^{1,2,{ }^{*}}$, R. Ait Babahmad ${ }^{2,4}$, H. Aboussaid ${ }^{1,2}$, Y. Atibi ${ }^{3}$, A. Aimrane ${ }^{1}$, K. Oufdou ${ }^{2}$ and S. El Messoussi ${ }^{1}$ \\ ${ }^{1}$ Laboratory of Molecular and Ecophysiology Modelling, Faculty of Sciences Semlalia, University Cadi Ayyad, \\ Marrakech, BP 2390, 40000 Morocco. \\ ${ }^{2}$ Laboratory of Microbial Biotechnologies, Agrosciences and Environment, Faculty of Sciences Semlalia, University \\ Cadi Ayyad, Marrakech, BP 2390, 40000 Morocco. \\ ${ }^{3}$ Laboratory of Biodiversity and Ecosystem Dynamics, Faculty of Sciences Semlalia, University Cadi Ayyad, Marrakech, \\ BP 2390, 40000 Morocco. \\ ${ }^{4}$ MARK Herbarium, Department of Biology; Faculty Semlalia, Cadi Ayyad University, Marrakech, BP 2390, 40000 \\ Morocco \\ *Corresponding author's e-mail address: alahyanerh@gmail.com
}

\begin{abstract}
Laboratory bioassays were conducted to evaluate the acaricidal activities of the ethanolic extract of Jatropha curcas L. leaves (Family: Euphorbiaceae) against adult females of oriental red mite, Eutetranychus orientalis. The leaf dip technique and direct application were adopted to assess the toxicity, fertility, repellency and ovicidal effects of different doses $(0.1-10 \mathrm{mg} / \mathrm{mL})$ of the ethanolic extracts of $J$. curcas L. leaves. We found that this extract increased mortality and reduced fecundity in a dose-dependent manner. Leaf discs treated with increasing doses $(0.05,0.5,1 \mathrm{and} 5 \mathrm{mg} / \mathrm{mL}) \mathrm{of}$ the extract also showed a high percentage of repellency (94.12\%) while treated eggs with these increasing doses showed a remarkable increase in the eggs' mortality 7 days after treatment, i.e., $72.00 \%$ at $5 \mathrm{mg} / \mathrm{mL}$. We confirmed the presence of secondary metabolites and showed an abundance of phenolic compounds, flavonoids, flavonols and tannins with different concentrations.
\end{abstract}

Keywords: Jatropha curcas L. extract, Eutetranychus orientalis, repellency, ovicidal effect, secondary metabolites.

https://doi.org/10.36899/JAPS.2020.5.0133

Published online June 25, 2020

\section{INTRODUCTION}

Eutetranychus orientalis (Klein), oriental red mite, is an important pest of a wide range of medicinal, ornamental and agriculture plants (Rasmy, 1978). This species has a wide distribution, so it can be found in the Middle East, Asia and Africa (Walter et al., 1995). Moreover, E. orientalis belongs to the quarantine list of the "European and Mediterranean Plant Protection Organisation (EPPO)". In Morocco, E. orientalis was detected for the first time in the Marrakech region in 2008 on citrus orchards, and then it spread to all regions known for citrus production (Abbassi, 2011). Since then, this mite has caused catastrophic damage to plants by piercing the upper surface of leaf cells and sucking out the sap. On the surface of damaged leaves, yellowishwhite spots appear (indicating destroyed chlorophyll). Afterward, the leaf turns yellow when the infestation increases. In severe infestations, the branches die back and the leaves fall which may induce tree defoliation.

Controlling E. orientalis in Morocco has been almost exclusively focused on synthetic acaricides as they are easy to apply and act rapidly. However, due to the continuous use of pesticides, many mites have developed resistance to most available acaricides (Imani et al., 2009). Moreover, the use of these acaricides has harmful effects on human health and the environment (Akyazi et al., 2015). Hence, there is an increasing necessity to discover natural products (e.g.: botanical acaricides) that can replace synthetic acaricides and control this mite.

Many plant extracts have shown a great acaricidal, ovicidal and repellency effects against arthropods (da Camara et al., 2015). In fact, these effects beings so important several studies have been conducted to assess the efficiency of a wide range of plants extracts including the extracts of Prunus laurocerasus L. (Rosaceae) (Akyazi et al., 2015), Rosmarinus officinalis L., Salvia officinalis L., Origanum compactum Benth and Thymus capitatus (L.) (Lamiaceae) (Salman et al., 2013; Aissaoui et al., 2018), Francoeria crispa (Forsk.) (Amira et al., 2011), Calotropis procera (Ait) (Apocynaceae), Nerium oleander L. (Apocynaceae) (Islam et al., 2008) and Leucaena glauca (Benth) (Auamcharoen and Chandrapatya, 2015). The observed effects are mainly due to the secondary metabolites contained in the plants, supposed to protect them against pests and pathogens. 
Among the evaluated plant extracts, Jatropha curcas L. is a species that belongs to the Euphorbiaceae family originating from Central America. The plant is used in traditional medicine to cure many diseases like dermatological infections (Papazoglou, 2014), parasite infections (Van der Vossen and Mkamilo, 2007) and cancer (Sabandar et al., 2013). The J. curcas extract has also shown an antimicrobial (Sharma et al., 2016; Ait Babahmad et al., 2018), and insecticidal properties (Ingle et al., 2017).

Some previous studies reported the acaricidal activity of ethanolic and aqueous extracts of $J$. curcas leaves (Juliet et al., 2012; Syahputraa and Endartob, 2013; Ahuchaogu et al., 2014). The acaricidal activity of the methanol extract of $J$. curcas leaves against the twospotted spider, Tetranychus urticae Koch (Acari: Tetranychidae) was also investigated (Abu-Shosha and Azzaz, 2015). These reveal the possibility of the existence of more potential effects of this extract on other devastating mites' species. To our knowledge, no research about the effect of $J$. curcas extracts on $E$. orientalis has been conducted. Thus, this study aimed to evaluate the acaricidal, fertility, repellency and ovicidal effects of the ethanolic extract of $J$. curcas against adult females and eggs of E. orientalis under laboratory conditions.

\section{MATERIALS AND METHODS}

Plant Material: Jatropha curcas L. leaves were collected from Had Dra region in Essaouira city, Morocco [31 34'39.56" N, 09 32'19.45" W] in November 2016. A specimen of the plant was taxonomically identified by Prof. Ahmed OUHAMMOU (Department of Biology, Faculty of Science Semlalia, University Cadi Ayyad, Marrakech, Morocco). The voucher specimen (Mark 10027) of J. curcas was deposited at Regional Herbarium MARK of the Faculty of Science Semlalia, University Cadi Ayyad, Marrakech (Morocco). The plant leaves were dried at $30-40^{\circ} \mathrm{C}$ for 5 days in an oven.

Preparation of ethanolic extract of $\boldsymbol{J}$. curcas leaves: The dry leaves of $J$. curcas were powdered using a mortar and screened through a muslin screen. A dried powder (40 g) was taken and soaked in ethanol (solvent was added at a rate of $1 \mathrm{mg} / 5 \mathrm{~mL}$ solvent). The mixtures were mechanically shaken for $48 \mathrm{~h}$ under laboratory conditions. The extract was filtered and then evaporated until dryness by using a rotary evaporator under vacuum at $40-50^{\circ} \mathrm{C}$. The crude material obtained was weighed and dissolved in the ethanol solvent at the ratio $1 \mathrm{~g} / 10$ $\mathrm{mL}$ solvent. Finally, the obtained extract was stored in a freezer until evaluation and HPLC analysis. The concentrated sample was subjected to the HPLC analysis after dilution.
Rearing of $\boldsymbol{E}$. orientalis: E. orientalis was collected from citrus orchards of Agafay (Agafay, Marrakech, Morocco). Collected mites were reared continuously on bean plants (Phaseolus vulgaris L.) under laboratory conditions at $25 \pm 2{ }^{\circ} \mathrm{C}$ and $65 \pm 5 \% \mathrm{RH}$, and with a $16: 8$ h (L:D) photoperiod.

Determination of total polyphenols content: The FolinCiocalteu colorimetric method (Singleton et al., 1965) was followed to determinate the total phenolic content. $0.1 \mathrm{~mL}$ of ethanolic extract of $J$. curcas leaves was added to $3.9 \mathrm{~mL}$ of ethanol followed by $0.1 \mathrm{~mL}$ of FolinCiocalteu reagent and the resulted solution was agitated. The agitated solution was then incubated for 3 min then 1 $\mathrm{mL}$ of $20 \%$ sodium carbonate $\left(\mathrm{Na}_{2} \mathrm{CO}_{3}\right)$ was added. The mixture was also agitated with a vortex and incubated at room temperature in darkness for one hour. At $725 \mathrm{~nm}$ using a spectrophotometer, the absorbance of our solution and the blank was measured. Results were expressed as mg gallic acid equivalents per kg of the dry matter (DM). All assays were carried three times.

Determination of total flavonoids: The method Aluminium Trichloride $\left(\mathrm{AlCl}_{3}\right)$ (Zhishen et al., 1999) was followed to determine flavonoids content by using catechin as a reference compound. $0.2 \mathrm{~mL}$ of ethanolic extract of $J$. curcas was mixed with $0.5 \mathrm{~mL}$ of distilled water and then added $60 \mu \mathrm{L}$ of a $5 \% \mathrm{NaNO}_{2}$ solution. The resulted solution was incubated for $6 \mathrm{~min}$. Afterward, we added to this solution $40 \mu \mathrm{L}$ of aluminum trichloride $(10 \%)$ and then the mixture was left $5 \mathrm{~min}$ for incubation. Finally, $400 \mu \mathrm{L}$ of $\mathrm{NaOH}(1 \mathrm{M})$ and $500 \mu \mathrm{L}$ of distilled water were added to the reaction medium. The obtained solution was agitated with vortex and then left 15 min for incubation. The absorbance of the solution was read using a spectrophotometer at $510 \mathrm{~nm}$. The total flavonoids content of the ethanolic extract of $J$. curcas was expressed as $\mathrm{mg}$ of catechin equivalent per $\mathrm{kg}$ of the dry matter.

Total condensed tannin contents: The vanillin in acid medium method (Xu and Chang, 2007) was followed to estimate the total condensed tannins. $200 \mu \mathrm{L}$ of the ethanolic extract of $J$. curcas was versed in two-test tubes, the first for the witness test and the second for the sample. Afterward, we added $1 \mathrm{~mL}$ of concentrated hydrochloric acid and $2 \mathrm{~mL}$ of vanillin solution $(4 \%$ in ethanol) and the obtained mixture was left $15 \mathrm{~min}$ for incubation. The absorbance of this mixture was determined at $500 \mathrm{~nm}$ using a spectrophotometer. The results were expressed as $\mathrm{mg}$ of catechin equivalent per $\mathrm{kg}$ of the dry matter.

Flavanols concentration: The derivatization with p(dimethylamino)-cinnamaldehyde (DMACA) method (Nigel and Glories, 1991) was followed to determinate flavanols content. $0.2 \mathrm{~mL}$ of the ethanolic extract of $J$. curcas was introduced to assay tubes and then $0.5 \mathrm{~mL}$ 
DMACA solution $(0.2 \%$ in ethanol) and $0.5 \mathrm{~mL}$ of $\mathrm{HCl}$ $(0.24 \mathrm{~N}$ in ethanol) were added. Afterward, the mixture was incubated $5 \mathrm{~min}$ at room temperature; the absorbance was read at $640 \mathrm{~nm}$. The witness was realized by using ethanol instead of the sample. From the absorbance data, a calibration curve was plotted and using catechin as standard, the total flavanols content was calculated. The results are expressed as $\mathrm{mg}$ of catechin equivalents per $\mathrm{Kg}$ of the dry matter.

Analysis by High Performance Liquid Chromatography (HPLC): The chromatographic analysis of phenolic compounds in leaves of $J$. curcas was approved using an HPLC (Knauer) equipped with a PDA detector (200-700 UV-Vis) and pump K-1001 running at $280 \mathrm{~nm}$ (Alahyane et al., 2019). The column (solid phase) used for separation was Eurospher II $100 \AA$ $5 \mu \mathrm{m}(4.6 \times 250 \mathrm{~mm})$. The temperature was fixed at $25^{\circ} \mathrm{C}$. The injection volume was $10 \mu \mathrm{L}$ and the flow rate was $1 \mathrm{~mL} / \mathrm{min}$. The mobile phase consists of a gradient of acetonitrile and bidistilled water acidified to $\mathrm{pH} 2.6$ with o-phosphoric acid and then filtered on Millipore $(0.45$ $\mu \mathrm{m})$. The mobile phase composed of acidified water and acetonitrile 5\%:95\% (v/v). The total time of analysis was one hour and the separation was performed on a gradient of $5 \%$ to $95 \%$ acetonitrile. The identification of phenolic compounds was realized by comparison of retention times with the standards.

Toxicity effects of ethanolic extract of $J$. curcas to female stages of $\boldsymbol{E}$. orientalis: Toxicity of ethanolic extract of $J$. curcas leaves to E. orientalis was evaluated following Cowles et al. (2000) method, with minor modifications. Bean leaves discs were dipped for five seconds in seven concentrations $0.1,0.5,1,2.5,5,7.5$ and $10 \mathrm{mg} / \mathrm{mL}$ of $J$. curcas extract. In the negative and positive control, the discs were treated respectively with ethanol and commercial product (Abamectin 2\%). Afterward, the treated discs were placed with a lower surface on moist cotton wool in Petri dishes and then the discs were left to dry for 30 minutes at ambient temperature. Twenty adult females were transferred to treated leaf discs by using a fine brush. Each treatment was replicated five times. Mortality and the number of laid eggs were recorded 24, 48 and $72 \mathrm{~h}$ after treatments. The mortality of adult females was transformed by using Abbott's correction formula for natural mortality in the untreated control (Abbott, 1925).

Corrected mortality $(\%)=((B-A) /(100-A)) \times 100$

$A$ refers to the number of dead individuals in the control; B refers to the number of dead individuals in the application concentration.

Repellency and oviposition deterrence test for adult females of $\boldsymbol{E}$. orientalis: The repellence and oviposition deterrence of the ethanolic extract of $J$. curcas was released following the choice test method (Roh et al.,
2013) with minor modifications. Bean leaves discs were placed with a lower surface on moist cotton wool in Petri dishes. One half of each leaf disc was separately treated with five concentrations of $J$. curcas extract $(0.05,0.5,1$ and $5 \mathrm{mg} / \mathrm{mL}$ ) and the second half, served as the control, was treated only with ethanol. Ten adult females of $E$. orientalis were placed in the center of the treated disc. Each concentration (treatment) was replicated five times with each replicate consisting of 10 adult mites. The location of the adult females on treated and control discs was noted after $24 \mathrm{~h}$ after treatment (mites were considered as repelled when had left the treated discs). The number of eggs laid on each half was counted after $24 \mathrm{~h}$.

Ovicidal effects of ethanolic extracts of $J$. curcas against $\boldsymbol{E}$. orientalis: The ovicidal activity of the ethanolic extract of $J$. curcas was evaluated following Alahyane et al. (2019) method, with minor modifications. The bean leaf discs were placed with the lower side on moist cotton wool in Petri dishes. Twenty adult females' mites were introduced to bean leaf disc for oviposition and kept 24 hours in Petri disc. After 24 h, the introduced mites were removed using a fine brush. The eggs laid on the bean leaves were counted under a binocular microscope, the leaves containing more than 20 eggs, the excess of eggs was removed. Eggs laid on leaf discs were treated with four concentrations of $J$. curcas extract $(0.05,0.5,1$ and $5 \mathrm{mg} / \mathrm{mL})$, using the dip method. The negative control was treated with ethanol, and the positive control was treated with a commercial product (Abamectin 2\%). The number of hatching eggs was counted 7 days after treatment. Those that did not hatch after this period were considered as dead.

Statistical analysis: Corrected mortality, number of eggs laid by adult females and mortality of eggs were subjected to analysis of variance (ANOVA). Tukey's test was used to assess the significant differences between treatments. All analyses were conducted using SPSS software (SPSS, 2010). To calculate the lethal concentrations $\left(\mathrm{LC}_{50}\right.$ and $\left.\mathrm{LC}_{90}\right)$ values, the probit analysis program version 1.5 was used. The formulas of Lwande et al. (1985) and Lundgren (1975) were used to calculate the repellency effect and the oviposition deterrent indices (ODI), respectively.

\section{Oviposition Deterrent Indices $(\%)=((B-A) /(A+B)) \times$ 100}

Where, A refers to the mean number of eggs laid on the treatment, B refers to the mean number of eggs laid on the control.

\section{Repellency effect $(\%)=\mathbf{2 A} /(\mathrm{A}+\mathrm{B}) \times \mathbf{1 0 0}$}

Where, A refers to the number of adult females on the control half-disc, B refers to the number of adult females on the treated half-disc. 


\section{RESULTS}

Total phenolic, flavonoids, condensed tannins and flavanols contents quantification: Table 1 shows the results of the quantification of total phenolic, flavonoids, condensed tannins and flavanols contents. We report a high concentration of tannins $(80.1 \pm 3.55 \mathrm{mg}$ catechin eq/1 Kg DM) and total flavanols $(67.7 \pm 3.45 \mathrm{mg}$ catechin eq/1 kg DM), while the total phenolic content was estimated at $(2 \pm 0.23 \mathrm{mg}$ gallic acid eq/ $1 \mathrm{~kg} \mathrm{DM})$ and the flavonoids at $(33.45 \pm 0.65 \mathrm{mg}$ catechin eq $/ 1 \mathrm{~kg} \mathrm{DM})$.

Table 1. Total phenolic compounds, Total flavonoids compounds, Total tannins and Total flavanols of $J$. curcas ethanolic extracts. All determinations were carried out at least in triplicate and values were averaged and given along the standard deviation $( \pm \mathrm{SD})$.

\begin{tabular}{cccc}
\hline $\begin{array}{c}\text { Total phenolic } \\
\text { (mg gallic acid } \\
\text { eq/ kg DM) }\end{array}$ & $\begin{array}{c}\text { Total Flavonoids } \\
\text { (mg catechin } \\
\text { eq/ kg DM) }\end{array}$ & $\begin{array}{c}\text { Total tannins } \\
\text { (mg catechin } \\
\text { eq/ kg DM) }\end{array}$ & $\begin{array}{c}\text { Total Flavanols } \\
\text { (mg catechin } \\
\text { eq/ kg DM) }\end{array}$ \\
\hline $20.34 \pm 0.23$ & $33.45 \pm 0.65$ & $80.1 \pm 3.55$ & $67.7 \pm 3.45$ \\
\hline
\end{tabular}

HPLC analysis: Fig. 1 shows that HPLC analysis of the ethanolic extract of $J$. curcas revealed the presence of several phenolic components namely gallic acid, catechin, vanillic acid, rutin, vanillin and p-coumaric acid.

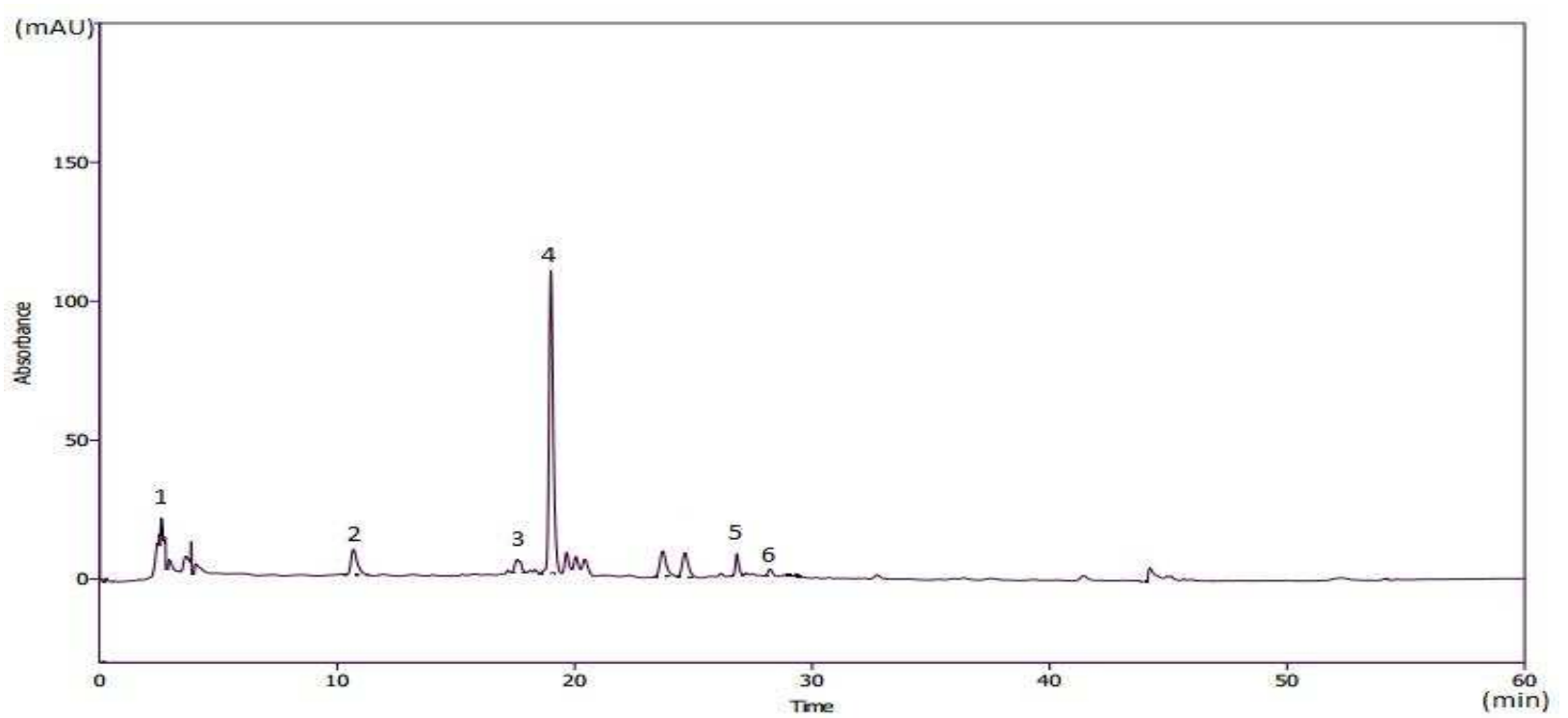

Figure 1. HPLC chromatogram recorded at $280 \mathrm{~nm}$ for the main phenolic compounds identified in the ethanolic extracts of $J$. curcas. 1: gallic acid; 2: catechin; 3: vanillic acid; 4: rutine; 5: vanillin; 6: p-coumaric acid.

Acaricidal activity of ethanolic extracts of $\boldsymbol{J}$. curcas against females of $\boldsymbol{E}$. orientalis: Table 2 shows mortality rates obtained by the contact effect of ethanolic extract of $J$. curcas against adult E. orientalis females. The mean mortality of $E$. orientalis females differed significantly with time and concentrations $(\mathrm{P}<0.05)$.

The acaricidal effect of the ethanolic extract of $J$. curcas was time and concentration-dependent. All concentrations caused adult female mortality starting from $24 \mathrm{~h}$ after treatment and the mortality increased with time. The commercial acaricide has a significantly higher mortality than the lower concentration of ethanolic extract, but at the highest concentration of extract (10 $\mathrm{mg} / \mathrm{mL}$ ) that induced a corrected mortality $96.66 \%$ did not differ significantly from the commercial acaricide (product based on Abamectin), which induced a corrected mortality of $95.77 \%$ after $72 \mathrm{~h}$ (Table 2).

A summary of probit analyses of mortality data for E. orientalis exposed to seven concentrations of ethanolic extracts of $J$. curcas leaves after $24 \mathrm{~h}, 48 \mathrm{~h}$ and $72 \mathrm{~h}$ are presented in Table 3. The lethal concentration ( $\mathrm{LC}_{50}$ and $\mathrm{LC}_{90}$ ) decreased with an increasing time of treatment of $E$. orientalis females and the probit analysis showed that the concentrations of the ethanolic extract of $J$. curcas leaves, which killed $50 \%$ and $90 \%$ of females after $72 \mathrm{~h}$, were $0.917 \mathrm{mg} / \mathrm{mL}$ and $13.534 \mathrm{mg} / \mathrm{mL}$, respectively. 
Table 2. Corrected mortality (\%) in adult females of $E$. orientalis after treatment with ethanolic extracts of Jatropha curcas leaves.

\begin{tabular}{|c|c|c|c|}
\hline \multirow{2}{*}{ Concentration $(\mathrm{mg} / \mathrm{mL})$} & \multicolumn{3}{|c|}{ Corrected mortality \pm Standard Error ${ }^{\text {a }}$} \\
\hline & $24 \mathrm{~h}$ & $48 \mathrm{~h}$ & $72 \mathrm{~h}$ \\
\hline Negative control & $2 \pm 1.24^{\mathrm{a}}$ & $3.58 \pm 0.35^{\text {a }}$ & $4.29 \pm 0,43^{\mathrm{a}}$ \\
\hline Positive control ${ }^{b}$ & $85.77 \pm 2.94^{\mathrm{e}}$ & $92.85 \pm 2.74^{\mathrm{d}}$ & $95.77 \pm 1.11^{\mathrm{ef}}$ \\
\hline 10 & $41.83 \pm 3.46^{\mathrm{d}}$ & $89.24 \pm 4.80^{\mathrm{d}}$ & $96.66 \pm 2.22^{\mathrm{f}}$ \\
\hline 7.5 & $30.61 \pm 3.46^{\mathrm{cd}}$ & $64.51 \pm 7.52^{c}$ & $78.88 \pm 4.08^{\mathrm{de}}$ \\
\hline 5 & $29.59 \pm 2.97^{\mathrm{cd}}$ & $62.36 \pm 4.49^{c}$ & $72.22 \pm 4.30^{\text {cd }}$ \\
\hline 2.5 & $21.43 \pm 2.60^{\mathrm{bc}}$ & $52.68 \pm 6.67^{\mathrm{bc}}$ & $63.33 \pm 4.15^{\mathrm{cd}}$ \\
\hline 1 & $10.20 \pm 2.60^{\mathrm{ab}}$ & $46.23 \pm 5.10^{\mathrm{bc}}$ & $56.66 \pm 6.43^{\mathrm{bc}}$ \\
\hline 0.5 & $11.22 \pm 3.06^{\mathrm{ab}}$ & $33.33 \pm 4.98^{b}$ & $43.33 \pm 3.23^{b}$ \\
\hline 0.1 & $5.10 \pm 2.60^{\mathrm{a}}$ & $7.52 \pm 2.01^{\mathrm{a}}$ & $11.11 \pm 2.48^{\mathrm{a}}$ \\
\hline
\end{tabular}

${ }^{a}$ Means followed by the same letter in the same column weren't statistically different at $\alpha=0.05$ by Tukey test.

${ }^{\mathrm{b}}$ Distilled water + commercial acaricide (active ingredient Abamectin $2 \%$ ).

Table 3. Values $\left(\mathrm{LC}_{50,90}\right)$ indicating the activity of the ethanol extract of $J$. curcas leaves in inducing the mortality of $E$. orientalis females during three periods.

\begin{tabular}{cccccc}
\hline $\begin{array}{c}\text { Hours after } \\
\text { application }\end{array}$ & $\begin{array}{c}\mathbf{L C}_{\mathbf{5 0}} \\
(\mathbf{m g} / \mathbf{m L})\end{array}$ & $\begin{array}{c}\text { Lower and upper } \\
\text { limit of 95\% CI }\end{array}$ & $\begin{array}{c}\text { LC90 } \\
(\mathbf{m g} / \mathbf{m L})\end{array}$ & $\begin{array}{c}\text { Lower and upper limit } \\
\text { of 95\% CI }\end{array}$ & Slope \pm SE \\
\hline 24 & 27.011 & $15.022-77.727$ & 1297.654 & $293.748-25732.383$ & $0.762 \pm 0.133$ \\
48 & 1.709 & $0.629-3.337$ & 32.924 & $12.763-327.950$ & $0.997 \pm 0.182$ \\
72 & 0.917 & $0.300-1.755$ & 13.534 & $6.454-59.897$ & $1.096 \pm 0.182$ \\
\hline
\end{tabular}

The mean number of eggs laid by treated adult females is presented in Table 4. Significant differences in the number of eggs laid by mites were apparent between the females treated with different concentrations of the extract of $J$. curcas leaves $72 \mathrm{~h}$ after treatment. The females in the negative control laid a significantly higher number of eggs than the other concentrations of the extract and the positive control.

The concentrations between 2.5 and $10 \mathrm{mg} / \mathrm{mL}$ produced superior reductions of fecundity compared to the control $72 \mathrm{~h}$ after treatment. The commercial acaricide had a significantly higher effect compared to all concentrations tested.

Repellency and oviposition effects of ethanolic extracts of $\boldsymbol{J}$. curcas on $\boldsymbol{E}$. orientalis adult females: The results of repellency and oviposition effects are shown in Table 5. The females chose to lay their eggs and were fed on untreated half discs. The values of repellency varied between $74.00 \%$ and $94.12 \%$. The mean number of eggs laid after $24 \mathrm{~h}$ of treatment varied according to the concentration tested.

Ovicidal effects of ethanolic extracts of $\boldsymbol{J}$. curcas on $\boldsymbol{E}$. orientalis: Ovicidal effects observed 7 days after treatment are recorded in Table 6. There was a significant difference in egg mortality across all concentrations, commercial acaricide (abamectin) and control $(\mathrm{P}<0.05)$. The egg mortality caused by abamectin 7 days after treatment $(81 \pm 8.21 \%)$ was not significantly different from that of concentration $5 \mathrm{mg} / \mathrm{mL}$ of extract $(72 \pm 5.7 \%)$. Egg mortality increased with an increasing concentration of ethanolic extract of $J$. curcas.

Table 4. Means of eggs laid by $E$. orientalis females treated with the ethanol extract of $J$. curcas leaves after $27 \mathrm{~h}$ under.

\begin{tabular}{cc}
\hline $\begin{array}{c}\text { Concentration } \\
(\mathbf{m g} / \mathbf{m L})\end{array}$ & $\begin{array}{c}\text { Mean of eggs/female } \pm \text { Standard } \\
\text { Error }^{\text {a }}\end{array}$ \\
\hline Negative control $^{\text {Positive control }}{ }^{\mathrm{b}}$ & $2.63 \pm 0.26^{\mathrm{a}}$ \\
10 & $0.15 \pm 0.09^{\mathrm{e}}$ \\
7.5 & $0.17 \pm 0.05^{\mathrm{e}}$ \\
5 & $0.40 \pm 0.06^{\mathrm{de}}$ \\
2.5 & $0.37 \pm 0.05^{\mathrm{de}}$ \\
1 & $0.52 \pm 0.10^{\mathrm{cd}}$ \\
0.5 & $0.62 \pm 0.16^{\mathrm{cd}}$ \\
0.1 & $0.72 \pm 0.13^{\mathrm{c}}$ \\
$1.13 \pm 0.17^{\mathrm{b}}$ \\
\hline a Means followed by the same letter weren't statistically \\
different at $\alpha=0.05$ by Tukey test. \\
b Distilled water + commercial acaricide (active ingredient \\
Abamectin 2\%).
\end{tabular}


Table 5. Repellency percentages and oviposition of $E$. orientalis females treated with different concentrations of $J$. curcas leaves extract.

\begin{tabular}{cccccc}
\hline \multirow{2}{*}{ Concentration $(\mathbf{m g} / \mathbf{m L})$} & \multicolumn{2}{c}{ Number of eggs deposited/female/Day } & \multirow{2}{*}{ ODI } & Repellency (\%) \\
\cline { 2 - 3 } & Treated half-disc & Untreated half-disc & & & \\
\hline 5 & 0.04 & 0.68 & 89.84 & 94.12 \\
1 & 0.14 & 0.88 & 60.73 & 81.08 \\
0.5 & 0.18 & 1.00 & 70.35 & 79.55 \\
0.05 & 0.26 & & 66.85 & 74.00 \\
\hline
\end{tabular}

Table 6. Ovicidal effects $(\% \pm$ SD) of different concentrations of ethanolic extracts of $J$. curcas leave against $E$. orientalis eggs 7 days after treatment.

\begin{tabular}{cc}
\hline $\begin{array}{c}\text { Concentration } \\
(\mathbf{m g} / \mathbf{m L})\end{array}$ & $\begin{array}{c}\text { Mean ovicidal } \pm \text { Standard } \\
\text { Error }^{\mathrm{a}}\end{array}$ \\
\hline Negative control $^{\mathrm{a}}$ & $6 \pm 2.91^{\mathrm{a}}$ \\
Positive control $^{\mathrm{b}}$ & $81 \pm 3.67^{\mathrm{e}}$ \\
5 & $72 \pm 2.54^{\mathrm{de}}$ \\
1 & $55 \pm 3.53^{\mathrm{cd}}$ \\
0.5 & $49 \pm 6.96^{\mathrm{c}}$ \\
0.05 & $27 \pm 3.74^{\mathrm{b}}$ \\
\hline
\end{tabular}

a Means followed by the same letter weren't statistically different at $\alpha=0.05$ by Tukey test.

b Distilled water + commercial acaricide (active ingredient Abamectin 2\%).

\section{DISCUSSION}

Jatropha curcas L. is an industrial plant that belongs to the family Euphorbiaceae and has a long cultivation history in tropical Africa, Asia, and America (Heller, 1996). Different parts of this plant can be used for a wide range of purposes (Ait Babahmad et al., 2018). Seed and leaves extract of $J$. curcas has shown insecticidal and acaricidal properties and could be applied to agricultural applications (Rug and Ruppel, 2000; Adebowale et al., 2006).

Phytochemical screening of $J$. curcas leaves in Table 1 revealed the abundance of several biologically active compounds including phenolic compounds, flavonoids, condensed tannins and flavanols. The same secondary metabolites were previously confirmed in $J$. curcas leaves by Rampadarath et al. (2016) and Sharma et al. (2016). Although, Ebuehi and Okorie (2009), and Oyama et al. (2016) highlighted the presence of the same substances, with different concentrations. This could be attributed to different collecting periods, growing conditions and/or geographical origin of plants (Noudjou et al., 2007). Also, the HPLC analysis reveals the presence of gallic acid, rutin and vanillic acid, which agrees with the finding by Namuli et al. (2011).

The current study is, therefore, the first to demonstrate that $J$. curcas extract has acaricidal activities against important phytophagous mites, E. orientalis.
Plant compounds have been used as insecticides (Arnbio et al., 2006; Jide-ojo et al., 2013), antifeedants (Numa et al., 2015), ovicides (Mozaffari et al., 2012; Salman et al., 2013; Auamcharoen and Chandrapatya, 2015), acaricides (Harder et al., 2016; Juliet et al., 2016), repellents (Hussein et al., 2006) and oviposition deterrents (Raja et al., 2000).

The mortality effects of ethanolic extract of $J$. curcas leaves against $E$. orientalis females were concentration-dependent. These results are in agreement with the findings by Sivira et al. (2011) and Numa et al. (2015), who noted that the mortality of $T$. urticae adults increased with increasing concentrations of the applied extract. Araya and Emana (2009), found that the mortality of adult Zabrotes subfasciatus (Boheman) (Coleoptera: Bruchidae) treated with J. curcas extract was more than $90 \%$. Our results show that the mortality caused by the highest concentration of the extracts $(10$ $\mathrm{mg} / \mathrm{mL}$ ), which was $96.66 \%$, showed no significant difference with that of the commercial acaricide (active ingredient is Abamectin), which was $97.77 \%$. This concentration of ethanolic extract of $J$. curcas can be used as an alternative product to control this phytophagous species in the field.

The extract of $J$. curcas leaves exhibit the rapid acaricide effects toward the adult females after $24 \mathrm{~h}$ of treatment $\left(\mathrm{LC}_{50}=27.011 \mathrm{mg} / \mathrm{mL} ; \quad \mathrm{LC}_{90}=1297.654\right.$ $\mathrm{mg} / \mathrm{mL}$ ). This rapid action can be explained by both systemic and contact toxicity exhibited by the botanical extracts to Tetranychidae mites (Amira et al., 2011). The comparison between the $\mathrm{LC}_{50}$ and $\mathrm{LC}_{90}$ values for adult females 24 and $72 \mathrm{~h}$ after treatment showed that these values decreased with increasing time of contact of the $E$. orientalis females to the ethanolic extracts. Similar to our results, Teles et al. (2007) have reported that increasing the time of contact of the $T$. urticae adults to the product can affect the behavior of the mite, resulting in decreased lethal concentration values.

The ethanolic extracts of $J$. curcas reduced significantly the fecundity of $E$. orientalis adult females. These data are consistent with Soto et al. (2011), Mozaffari et al. (2012) and Numa et al. (2015), who postulated that the application of plant extract affects the oviposition and fecundity of Tetranychidae, which could be due to the probable sublethal effects of extracts on $T$. urticae females. 
In this study, a higher percentage of repellency effect on the $E$. orientalis females was noted at 0.5 $\mathrm{mg} / \mathrm{mL}(94.12 \%)$; Also, a higher oviposition deterrence was observed in the leaf discs treated with this concentration of the extract. Similar results were reported by Amira et al. (2011) who studied the effect of the extract of Francoeria crispa (Forsk.) against E. orientalis and found that this extract had a repellency effect on $E$. orientalis; reached $97.45 \%$ at higher concentration. Moreover, Jide-ojo et al. (2013) reported mortality and repellency efficacy of the extracts of $J$. curcas leaves against maize weevil, Sitophilus zeamais Motschulsky (Coleoptera: Curculionidae).

The ethanolic extract of $J$. curcas showed a great ovicidal effect on E. orientalis eggs. This result agrees with the finding of Yanar et al. (2011) who tested the methanolic extracts of Anthemis vulgaris L. and Lolium perenne L. on T. urticae eggs and obtained mortalities of $25.38 \%$ and $24.40 \%$, respectively. Moreover, many previous studies have shown that the botanical extracts exhibit excellent ovicidal effects on mite species (Roh et al., 2013; Pavela et al., 2016)

The toxicity of ethanolic extracts of $J$. curcas toward E. orientalis stages can be explained by the presence of secondary metabolites, such as phenolics, flavonoids, tannins, known for their insecticidal and acaricidal activities (Singh et al., 2014). Indeed, Mila et al. (1996) reported that the tannins are potently active against many pests and plant pathogens and they act by a combination of mechanisms that include iron chelation and enzyme inhibition (Karamanoli et al., 2011).

In conclusion, the extract of $J$. curcas leaves tested in this work had potent acaricidal, repellent, ovicidal and oviposition deterrent effects against the oriental red mite, E. orientalis. Phytochemical screening of the plant leaves revealed the presence of vital chemical compounds in phenomenal concentrations (phenolic compounds, tannins, flavonoids and flavanols). The isolation of these compounds responsible for the acaricidal activities in the extract of $J$. curcas leaves will be useful for the discovery of novel natural acaricides. These plant species could be used as alternatives in an integrated pest management program against $E$. orientalis, to reduce the problems related to the use of chemical acaricides.

Acknowledgments: The authors are grateful to Prof. Ahmed OUHAMMOU for his help in identifying the species used in this study.

\section{REFERENCES}

Abbassi, M. (2011). Acarien tétranyque menaces permanent sur les agrumes : Cas de l'acarien rouge oriental Eutetranychus orientalis. Agriculture du Maghreb, n 50 Mars 2011.
Abbott, W.S. (1925). A method of computing the effectiveness of an insecticide. J. Econ. Entomol. 18: 265-267.

Abu-Shosha, M.A.A. and N.E.A. Azzaz (2015). Comparative toxicity of some plant extracts on eggs and adult females of Tetranychus urticae Koch (Acari: Tetranychidae). J. Plant Prot. Patholo. 6(2): 323-31.

Adebowale, K.O. and C.O. Adedire (2006). Chemical composition and insecticidal properties of the underutilized Jatropha curcas seed oil. Afr. J. Biotechnol. 5(10): 901.

Ahuchaogu, C.E., F.O. Ojiako, and J.D. Kabeh (2014), Evaluation of Jatropha curcas L. extracts in the control of some field insect pests of cowpea (Vigna unguiculata L. Walp). Inter. J. Sc. Tech. Res. 3(3): 136-141.

Aissaoui, B.A., A. El-Amrani, S. Zantar, and L. Toukour (2018). Activité Acaricide des huiles essentielles du Mentha pulegium, Origanum compactum et Thymus capitatus sur l'acarien phytophage Tetranychus urticae Koch (Acari: Tetranychidae). Eur. Sci. J. 14(3): 119-124.

Akyazi, R., S. Mete, and H. Errol (2015). Toxic and repellent effects of Prunus laurocerasus L. (Rosaceae) extracts against Tetranychus urticae Koch (Acari: Tetranychidae). Turk. Entomol. Derg. 39(4): 367-80.

Alahyane, H., A. El Alaoui, H. Aboussaid, A. Aimrane, Y. Atibi, K. Oufdou and S. El Messoussi (2019). Biological activity of some native Bacillus thuringiensis Berliner strains against Eutetranychus orientalis (Klein) (Acari: Tetranychidae). Appl. Ecol. Env. Res. 17(2): 1967-1977.

Alahyane, A., H. Harrak, J. Ayour, I. Elateri, A. Aitoubahou, and M. Benichou (2019). Bioactive compounds and antioxidant activity of seventeen Moroccan date varieties and clones (Phoenix dactylifera L.). S. Afr. J. Bot. 121: 402-409.

Amira, A., A. Sanaa, and M. Faten (2011). Repellency and toxicity of extract from Francoeria crispa (Forsk.) to Eutetranychus orientalis (Klein) (Acari: Tetranychidae). Arch. Phytopathology Plant Protect. 44(5): 441-50.

Araya, G.S. and G. Emana (2009). Evaluation of botanical plants powders against Zabrotes subfasciatus (Boheman) (Coleoptera: Bruchidae) in stored haricot beans under laboratory condition. Afr. J. Agric. Res. 4(10): 1073-1079.

Arnbio, V.J., F.B. Brigitte, H. Guénego, and F.M. Diego (2006). Effect of Jatropha gossypiifolia leaf extracts on three Lepidoptera species. Rev. Colomb. Entomol. 32(1): 45-48.

Auamcharoen, W. and A. Chandrapatya (2015). Acaricidal and ovicidal efficacies of Leucaena 
glauca Bneth. seed crude extracts on Tetranychus urticae Koch (Acari: Tetranychidae). J. Biopest. 8(2): 68-81.

Ait Babahmad, R., A. Aghraz, A. Boutafda, E.G. Papazoglou, P.A. Tarantilis, C. Kanakis, M. Hafidia, Y. Ouhdouche, A. Outzourhitf, and A. Ouhammou (2018). Chemical composition of essential oil of Jatropha curcas L. leaves and its antioxidant and antimicrobial activities. Ind. Crop. Prod. 121: 405-410.

Cowles, R., E. Cowles, A. McDermott, and D. Ramoutar, (2000). "Inert" formulation ingredients with activity: toxicity of Trisiloxane surfactant solutions to two spotted spider mites (Acari: Tetranychidae). J. Econ. Entomol. 2: 180-188.

da Camara, C.A., Y. Akhtar, M.B. Isman, R.C. Seffrin, and F.S. Born (2015). Repellent activity of essential oils from two species of Citrus against Tetranychus urticae in the laboratory and greenhouse. Crop. Prot. 74: 110-115.

Ebuehi, O.A.T. and N.A. Okorie (2009). Phytochemical screening and quantification of flavonoids from leaf extract of Jatropha curcas L. Nig. Q. J. Hosp. Med. 19(4).

Harder, M.J., V.E. Tello, and J.H. Giliomee (2016). The acaricidal effect of ethanolic extracts of Chenopodium quinoa Willd on Tetranychus urticae Koch (Acari: Tetranychidae). Afr. Entomol. 24(1): 50-60.

Heller, J. (1996). Jatropha curcas L. promoting the conservation and use of underutilized and neglected crops. I. Institute of Plant Genetics and Crop Plant Research/ International Plant Genetic Resources Institute, Rome. Physic Nut.

Hussein, H., M. Abou-Elella, S.A.A. Amer, and F.M. Momen (2006). Repellency and toxicity of extracts from Capparis aegyptia L. to Tetranychus urticae Koch (Acari: Tetranychidae). Acta. Phyto. Entom. Hung. 41: 331-340.

Imani, Z., P. Shishehbor, and F. Sohrabi (2009). The effect of Tetranychus turkestani and Eutetranychus orientalis on the development and reproduction of Stethorus gilvifrons. J. Asia Pac. Entomol. 12: 213-16.

Ingle, K.P., A.G. Deshmukh, D.A. Padole, M.S. Dudhare, and M. Pradip (2017). Antibacterial activity of Jatropha curcas extract against Pseudomonas fluorescence and Xanthomonas auxinopodis. J. Pharmacogn. Phytochem. 6(6): 2169-2173.

Islam, M.T., M.M. Haque, N. Naher, and S. Parween (2008). Effect of plant materials on developmental periods of two spotted spider mite Tetranychus urticae Koch (Acari: Tetranychidae). Int. J. Biol. Sci. 16: 121-124.
Jide-Ojo, C., T.G. Daniel, and O.O. Opeolu (2013). Extracts of Jatropha curcas L. exhibit significant insecticidal and grain protectant effects against maize weevil, Sitophilus zeamais (Coleoptera: Curculionidae). J. Stored Prod. Postharvest Res. 4(3): 44-50.

Juliet, S., R. Ravindran, S.A. Ramankutty, A.K.K. Gopalan, S.N. Nair, A.K. Kavillimakkil, A. Bandyopadhyay, S.A.K. Rawat, and S. Ghosh (2012). Jatropha curcas L. leaf extract-a possible alternative for population control of Rhipicephalus annulatus. Asian Pac. J. Trop. Dis. 2(3) : 225-229.

Karamanoli, K., P. Bouligaraki, H.I.A. Constantinidou, and S.E. Lindow (2011). Polyphenolic compounds on leaves limit iron availability and affect growth of epiphytic bacteria. Ann. Appl. Biol. 159: 99-108.

Lundgren, L. (1975). Natural plant chemicals acting as oviposition deterrents on cabbage butterflies Pieris brassicae (L.), Pieris rapae (L.) and Pieris napi (L.). Zool. Sci. 4: 253-258.

Lwande, W., P.W. Hassanali, P.W. Njoroge, M.D. Bentely, M.F. Delle, and J.I. Jondiko (1985). A new 6, a-hydroxyl pterocarpon with insect antifeedant and antifungal properties from the roots of Tephrosia hildebrantii Vatke. Insect Sci. Appl. 6: 534-547.

Mila, I., A. Scalbert, and D. Expert (1996). Iron withholding by plant polyphenols and resistance to pathogens and rots. Phytochemistry 42: 1551555.

Mozaffari, F., H. Abbasipour, A.S. Garjan, A.R. Saboori, and M. Mahmoudvand (2012). Various effects of ethanolic extract of Mentha pulegium on the two-spotted spider mite, Tetranychus urticae (Tetranychidae). Arch. Phytopathology Plant Protect. 45(11): 1347-55.

Namuli, A., N. Abdullah, C.C. Sieo, S.W. Zuhainis, E. Oskoueian (2011). Phytochemical compounds and antibacterial activity of Jatropha curcas Linn. extracts. J. Med. Plants Res. 5(16): 39823990.

Nigel, C.W. and Y. Glories (1991). Use of a modified dimethylaminocinnamaldehyde reagent for analysis of flavanols. Am. J. Enol. Vitic. 42(4): 364-366.

Noudjou, F., H. Kouninki, L.S.T. Ngamo, P.M. Maponmestsem, M. Ngassoum, T. Hance, E. Haubruge, F. Malaisse, M. Marlier, and G.C. Lognay (2007). Effect of site location and collecting period on the chemical composition of Hyptis spicigera Lam. an insecticidal essential oil from North-Cameroon. J. Essent. Oil Res. 19: 597-601. 
Numa, S., L. Rodriguez, D. Rodriguez, and E. CoyBarrera (2015). Susceptibility of Tetranychus urticae Koch to an ethanol extract of Cnidoscolus aconitifolius leaves under laboratory conditions. SpringerPlus, 4(1): 338.

Oyama, M.O., O.I. Malachi, and A.A. Oladejo (2016). Phytochemical screening and antimicrobial activity of leaf extract of Jatropha curcas. J. Adv. Medi. Pharma. Sc. 8(1): 1-6.

Papazoglou, E.G. (2014). Jatropha curcas L.: A multipurpose energy crop. Fresenius Environ. Bull. 23: 2695-2699.

Pavela, R., E. Stepanycheva, A. Shchenikova, T. Chermenskaya, and M. Petrovab (2016). Essential oils as prospective fumigants against Tetranychus urticae Koch. Ind. Crop Prod. 94: 755-61.

Raja, N., S. Albert, S. Ignacimuthu, T.I. Ofuya, and S. Dorn (2000). Role of botanical protectants and larval parasotoid Dinarmus vagabundus (Timberlake) (Hymenoptera: Pteromalidae) against Callosobruchus maculatus (Fab.) (Coleoptera: Bruchidae) infesting cowpea seeds. Malay. Appl. Biol. 29(1): 255-260.

Rampadarath. S., D. Puchooa, and R. Jeewon (2016). Jatropha curcas L: Phytochemical, antimicrobial and larvicidal properties. Asian Pac. J. Trop. 6(10): 858-865.

Rasmy, A.H. (1978). Biology of citrus brown mite, Eutetranychus orientalis (Klein) as affected by some citrus species. Acarologia, 19: 222-224.

Roh, H.S., B.H. Leen, and C.G. Park (2013). Acaricidal and repellent effects of myrtacean essential oils and their major constituents against Tetranychus urticae (Tetranychidae). J. Asia Pac. Entomol. 16: 245-249.

Rug, M. and A. Ruppel, (2000). Toxic activities of the plant Jatropha curcas against intermediate snail hosts and larvae of schistosomes. Trop. Med. Int. Health. 5: 423-430.

Sabandar, C.W., N. Ahmat, F.M. Jaafar, and I. Sahidin, (2013). Medicinal property, phytochemistry and pharmacology of several Jatropha species (Euphorbiaceae): a review. Phytochemistry. 85: 7-29.

Salman, Y.S., S. Saritas, N. Kara, and R. Ay (2013). Acaricidal and ovicidal effects of sage (Salvia officinalis L.) and rosemary (Rosmarinus officinalis L.) extracts on Tetranychus urticae Koch (Acari: Tetranychidae). Am. J. Enol. Vitic. 20: 358-67.

Sharma, A.K., M. Gangwar, D. Kumar, G. Nath, A.S.K. Sinha, and Y.B. Tripathi (2016). Phytochemical characterization, antimicrobial activity and reducing potential of seed oil, latex, machine oil and presscake of Jatropha curcas. Avicenna J. Phytomed. 6(4): 366.

Singh, H., S. Dixit, P.C. Verma, Singh, P.K. (2014). Evaluation of total phenolic compounds and insecticidal and antioxidant activities of tomato hairy root extract. J. Agr. Food. Chem. 62(12): 2588-2594.

Singleton, V.L. and J.A. Rossi, (1965). Colorimetry of total phenolics with phosphomolybdicphosphotungstic acid reagents. Am. J. Enol. Vitic. 16: 144-158.

Sivira, A., M.E. Sanabria, N. Valera, and C. Vasquez (2011). Toxicity of ethanolic extracts from Lippia origanoides and Gliricidia sepium to Tetranychus cinnabarinus (Boisduval) (Acari: Tetranychidae). Neotrop. Entomol. 40(3): 375379.

Soto, A., H.G. Oliveira, and A. Pallini (2011). Integración de control biológico y de productos alternativos con Tetranychus urticae (Acari: Tetranychydade). Revista U.D.C.A Actualidad and Divulgación Científica. 14(1): 23-29.

Syahputraa, E. and O. Endartob (2013). Acaricidal activity of tropical plant extracts against citrus mites and their effect on predator and citrus plants. Inter. Res. J. Agri. Sc. Soil Sc. 3(4): 99106.

Teles, P.W., J.C. Selva, and C.A. Gómes (2007). Actividade acaricida dos óleos essencias de folias e frutos de Xylopia sericea sobre o ácaro rajado (Tetranychus urticae Koch). Química. Nova. 30(4): 838-841.

Van der Vossen, H.A.M. and G.S. Mkamilo (2007). Plant Resources of Tropical Africa. Vegetable Oils. Backhuys, Wageningen. $237 \mathrm{p}$

Walter, D.E., R.B. Halliday, and D. Smith (1995). The oriental red mite, Eutetranychus orientalis (Klein) (Acarina: Tetranychidae), in Australia. J. Aust. Entomol. Soc. 34: 307-308.

$\mathrm{Xu}, \mathrm{B} . J$. and S.K.C. Chang (2007). A comparative study on phenolic profiles and antioxidant activities of legumes as affected by extraction solvents. J. Food Sci. 72: 159-166.

Yanar, D., K. Izzet, and G. Ayhan (2011). Acaricidal effects of different plant parts extracts on twospotted spider mite (Tetranychus urticae Koch). Afr. J. Biotechnol. 10(55): 11745-11750.

Zhishen, J., T. Mengcheng, and W. Jianming (1999). The determination of flavonoid contents in mulberry and their scavenging effects on superoxide radicals. Food Chem. 64: 555-559. 